\title{
Contractor's Technology Acceptance for Firm Sustainability Performance
}

\author{
J.A. Bamg bade ${ }^{1}$, Maruf Gbadebo Salimon², A.Q. Adeleke ${ }^{3}$, and Y. Nasidi ${ }^{4}$ \\ ${ }^{1}$ Faculty of Engineering, Computing and Science, Swinburne University of Technology, Sarawak, \\ Malaysia \\ ${ }^{2}$ Department of Marketing, School of Business Management, Universiti Utara Malaysia, Kedah, \\ Malaysia \\ ${ }^{3}$ Faculty of Industrial Management, Universiti Malaysia Pahang, Lebuhraya Tun Razak, 26300 \\ Gambang, Pahang, Malaysia \\ ${ }^{4}$ School Technology Management and Logistics, Universiti Utara Malaysia, Malaysia
}

\section{Abstract}

The construction industry's contributions to Greenhouse gas emissions have generated several discussions among the construction stakeholders in recent times. Granted that the construction industry has been contributing significantly to the economy as well as employment in most countries for decades, the industry's resource consumption is, at

Corresponding Author:

J.A. Bamgbade

jbamgbade@swinburne.edu.my

Received: 5 August 2019

Accepted: 14 August 2019

Published: 18 August 2019

Publishing services provided by

Knowledge E

(c) J.A. Bamgbade et al. This

article is distributed under the

terms of the Creative Commons

Attribution License, which

permits unrestricted use and

redistribution provided that the

original author and source are

credited.

Selection and Peer-review under the responsibility of the FGIC2019 Conference Committee. the same time, damaging to a sustained human environment. This paper empirically explored the organizational technology orientation and perceived organizational usefulness that could improve construction Malaysian construction firm's sustainability performance. Close-ended structured copies of questionnaire survey were employed to collect data from large Malaysian construction firms, and Partial Least SquaresStructural Equation Modeling technique was used to analyze the 172 responses. The results indicated that both technology orientation and perceived organizational usefulness are capable of influencing the construction firms' sustainability performance. The implication is that this study's model can predict the sustainability performance of the sampled construction firms. Some implications for research and practice, as well as future recommendations, were highlighted.

Keywords: sustainable construction, technology acceptance, perceived organizational usefulness, construction firms

\section{Introduction}

The insensitivity of the construction industry to environmental degradation, the societal needs, as well as its wasteful consumption of the finite resources, necessitated the continuous discussion about sustainable construction - a concept that addresses the environmental, social, and economic concerns of buildings within the context of its community (Kibert, 2016). In its original form, and as popularized by McDonough and Braungart (2010), sustainable construction encompasses the concept of cradle-tocradle design, which describes those novel construction approaches that employ an 
all-inclusive mentality or approach (see Figure 1). However, the full integration of sustainability in project delivery is yet to achieve satisfactory results. Aside from infusing IT solutions that can readily augment sustainability to realize mutually beneficial outcomes for all stakeholders, the perceived benefits (or perceived organizational usefulness) that the construction firms derive from implementing sustainability principles to enhance their performance within the industry is one of the lofty ways to go.

Attaining a superior performance in the present competitive business environment is becoming more challenging. Companies need to constantly utilize new technology to develop better products in order to create more value for consumers, attain high productivity, and remain competitive. These directions are important for 21st-century companies because the external environment where they operate is laden with choosy consumers who are getting more concerned with the added value they can derive from products (Reid \& Brady, 2012). In spite of ample evidence demonstrating how technology adoption in many industries has improved their sustainability performance, firms within the construction sector have always been laggard adopters of technological innovation. This explains why sustainability adoption is always a recurring issue in the industry, and attaining competitiveness has been attributed to the adoption of technologies like renewable energy, waste minimization, water efficiency and so forth (Zuo \& Zhao, 2014).

From the extant studies, Davis (1989) pioneered one of the widely adopted technology acceptance models, where he suggested several variables of technology acceptance. Ever since then, a series of studies have been carried out with the aim of extending and improving the model (Lee, Yu \& Jeong, 2013). In recent times, however, only a few studies on technology acceptance models within the construction sector were carried out. Chung et al., (2008) tested a technology acceptance model for the Enterprise Resource Planning (ERP) in construction, while the usability analysis of a Project Management Information System (PMIS) was observed by Nam et al., (2008). In spite of these efforts, studies on technology acceptance for sustainability reflecting the different views of contractors are scarce especially within the Malaysian construction industry context; therefore, the mechanisms for technology acceptance towards sustainability performance and achievements have not been properly defined.

Constructs adopted in this study are based on those discussed in technology adoption theories, and they were selected considering their relevance to sustainability as evidenced in the previous empirical and case studies on firm-level sustainability adoption (Bamgbade et al., 2017; Yusof et al., 2016). One of key elements of sustainability in building construction is to reduce resource consumption and improve the utilization 
efficiency of resources, where a common approach is to achieve an appropriate level of reduction, recycling and reuse (Yeheyis et al., 2013). These approaches are aimed at encouraging technology adoption in order to minimize construction and demolition impacts. In this paper, we sought to test the ability of technology orientation and perceived organizational usefulness in explaining the sustainability performance of construction firms in Malaysia.

Perceived organizational usefulness, which explains the degree to which an employee believes that using a system/technology would enhance his job or organizational performance, is an important construct in any technology acceptance model (Davis, 1989). This follows from how the concept of usefulness is defined in terms of the capability to utilize advantageously. The adoption of sustainable construction is possible when an individual is willing to integrate sustainability into a construction project delivery and when one's affiliated firm is willing to establish a cooperation system that integrates the dimensions of sustainable construction. Thus, the measurement items for perceived usefulness can be situated largely within organizational recognition that construction sustainability adoption improves firm performance and productivity.

This study's main purpose, however, is to develop, as well as validate the construction sustainability performance model based on the popular technology acceptance theories. This article is structured thus: First, the sustainability performance of construction firms is defined from the viewpoint of the technology acceptance model developed in previous studies. Second, based on a comprehensive literature review, a set of hypotheses on sustainability performance, technology orientation and perceived organizational usefulness are developed. Third, the methods and results of the survey conducted are presented. Lastly, theoretical and practical implications and directions for future studies are discussed. To generalize this study's findings, opinions of experienced construction experts (contractors, architects, project managers, engineers, quantity surveyors, contract managers, and sales managers) in the Malaysian construction industry were sampled. These respondents were spread across the construction firms in the eleven states in Peninsula Malaysia. Structural Equation Modeling was employed, where a 2-phased method was implemented. First, the estimation of the measurement model was done so as to assess the psychometric properties of the adapted scales. Second, the structural model was utilized to determine the path coefficients and the variance explained by the predictor variables. 


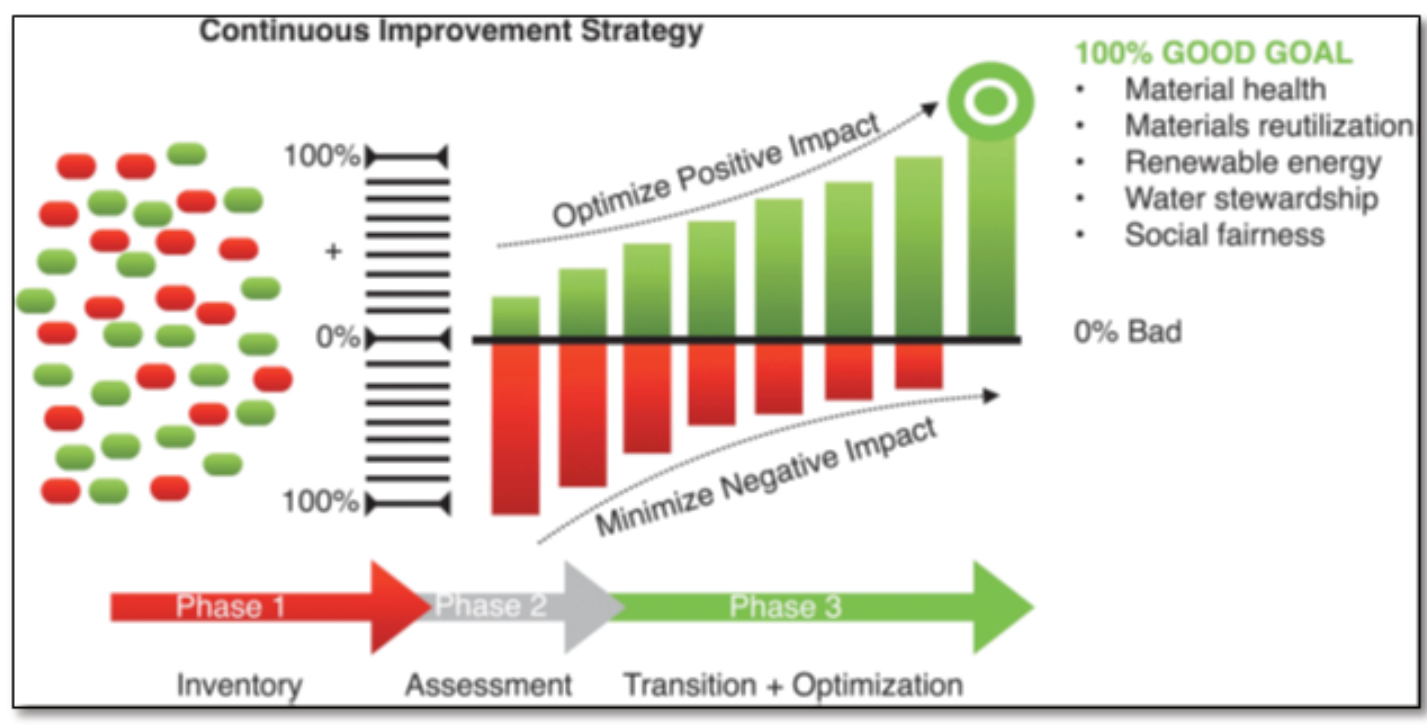

Figure 1: Cradle-to-cradle improvement process to attain sustainability (Source: Kibert, 2016).

\section{Literature Review}

\subsection{Technology orientation for sustainability performance}

Concerns about the effects of greenhouse gasses, climate change and environmental awareness have spurred interest in firms' sustainability performance within the construction industry (Bamgbade et al., 2019; Wong \& Zhou, 2015). It has been argued that firms' technology orientation holds a greater promise of being instrumental in dousing the negative environmental effects of the world's rapidly developing nations (Erek et al., 2009). A technology-oriented firm is rooted in the philosophy of "technological push" that favours the continuous application of new technologies, and this is vital in our conceptualization of firms' sustainability performance capability (Gatignon \& Xuereb, 1997).

Prior studies (e.g., Salimon et al., 2017; Wong \& Zhou, 2015) has outlined that over the past few decades, technologies such as Building Information Technology (BIM) and the Computer Aided Design (CAD) technology have metamorphosed the traditional mode of project delivery in both the emerging and the developed nations. While recent studies have dichotomized technology-push and customer-pull areas of research, the main argument in this section is that firms that are guided by technology orientation accumulate a vast amount of technical knowledge that they may use to their sustainability advantage (Salojärvi et al., 2015). Sustainability performance requires the firms to possess the distinctive capability to utilize new technologies for practices like pollution prevention and other environmental improvements in project delivery (Bhupendra \& 
Sangle, 2015). In this way, it is argued that technology orientation in firms will improve end-products performance by being competitive. Thus, we hypothesized that:

H1: The greater the technology orientation of construction firms, the higher will be their sustainability performance in project delivery.

\subsection{Perceived organizational usefulness for sustainability perfor- mance}

To completely adopt sustainability and improve construction project delivery based on the triple bottom line, both the employees (individuals) and the construction firm (group) must be willing to initiate sustainable construction approaches in their tasks within project realization. Granted that perceived usefulness has been used widely at both organizational and individual levels, a system is perceived useful when organizational users believe that the system has certain benefits that could improve their tasks and assist in achieving their given targets (e.g. Salimon et al., 2017). In the same way, when the project proponents believe that sustainable construction will enhance their productivity, they are more likely to explore its various characteristics (Rangarajan et al., 2005). Since organizational and individual incentives inspire users to perceive an application to be relevant, hence, perceived usefulness of the system could result in its actual usage and this may eventually lead to a wider application by all the members of the organization (Ackerman \& Halverson, 1998). Thus, perceived organizational usefulness is contingent on the perceived benefit, which translates perceived usefulness of sustainable construction into a cognitive process of what it can offer, and what organizational users need in order to perform their tasks effectively (Venkatesh \& Bala, 2008).

The items for individual intention to adopt sustainable construction include the willingness to utilize sustainable construction technology and information to fulfil tasks, willingness to spend the time to utilize sustainable construction technology, and the willingness to recommend sustainable construction technology to co-workers or other professionals in a cordial relationship. The indicators used in measuring organizational intention to adopt sustainable construction are the willingness to encourage the use of sustainable construction among group constituents, willingness to recommend the use of sustainable construction technology to other organizations in a cordial relationship, and the willingness to develop sustainable construction application technologies. 
H2: The greater the perceived organizational usefulness of construction firms, the higher will be their sustainability performance in project delivery

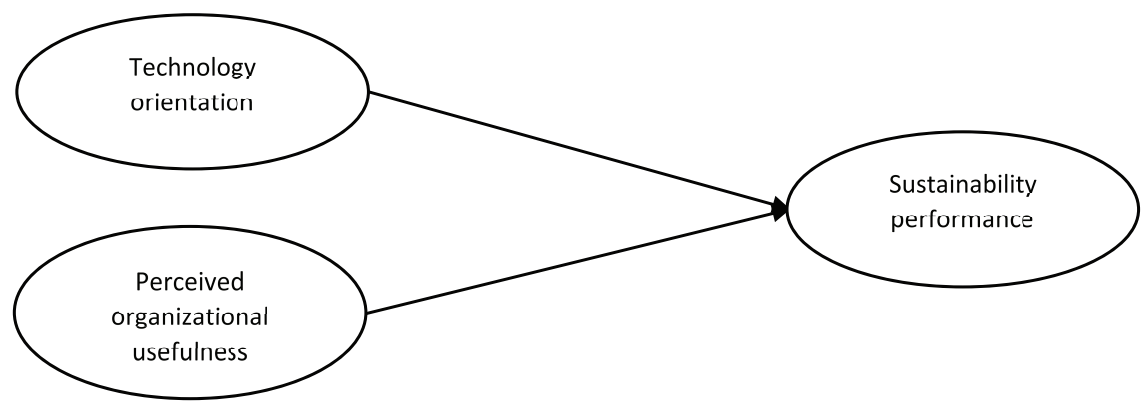

Figure 2: Research framework.

\section{Methodology}

We adopted a survey method in this study because it has been able to provide a sound basis for the establishment of study generalization, reliability, and statistical power (Dooley, 2001). The population of interest for this study includes CIDB (Construction Industry Development Board) registered and active large construction companies (within building construction and civil engineering categories), in West Malaysia. This population was obtained from the CIDB website.

\subsection{Construct operationalization}

As indicated in Table 1, we adopted a survey instrument from the previous studies, where all the individual items were assessed with the aid of a 5-point Likert scale ranging from 1 , not at all, to 5, completely true. The measures for TO were adopted from Gatignon \& Xuereb, (1997), and operationalized as a reflective construct. However, a few modifications were made to the original scales to make them relevant to the context of sustainability performance.

As for the measures of perceived organizational usefulness, the items for both individual and organizational usefulness (adapted from Davis, 1989) were combined for use in this context considering that sustainability performance (SP) of the construction firms is best achieved through a combination of both individual employee's commitment and firm willingness to improve its performance. Drawing on Abidin (2005), we operationalized SP as a reflective construct formed by three sub-constructs: EnSP, EcSP and SSP. EnSP was measured reflectively composing of eight indicators, EcSP was also 
measured reflectively with five indicators, while SSP was measured with another five items.

To ensure the content validity of the survey instrument, 4 construction practitioners were invited to participate in developing the final draft of the survey instrument. Another 4 faculty members were invited to review the instrument for additional feedback for improvement. The recommendations from both the industry experts and the faculty members were utilized to improve both face and content validities of the survey instrument in terms of the length of the instrument, the scales format, including the content and ambiguity of the items. Accordingly, a few changes were made in the wording of the items. A pilot study was also conducted involving forty-five construction practitioners. Their feedback was obtained in order to determine the internal consistency for each of this study's constructs.

TABLE 1: Variables and measurements.

\begin{tabular}{|c|c|c|c|}
\hline Variable name & Variable type & $\begin{array}{l}\text { Item description (1-5 Likert scale, } 1=\text { not at all, } 5= \\
\text { completely true) }\end{array}$ & Reference \\
\hline \multirow[t]{7}{*}{$\begin{array}{l}\text { Technology } \\
\text { orientation } \\
\text { (TO) }\end{array}$} & Reflective & $\begin{array}{l}\text { TO1. Our new products are always in the state of the } \\
\text { art of technology. }\end{array}$ & $\begin{array}{l}\text { Adapted from } \\
\text { Gatignon \& } \\
\text { Xuereb, } \\
\text { (1997) }\end{array}$ \\
\hline & & $\begin{array}{l}\text { TO2. Our organization is very proactive in the } \\
\text { development of new technologies. }\end{array}$ & \\
\hline & & $\begin{array}{l}\text { TO3. Our organization has the will and the capacity to } \\
\text { build and to market a technological breakthrough. }\end{array}$ & \\
\hline & & $\begin{array}{l}\text { TO4. Our organization has built a network of } \\
\text { relationships with suppliers of technological } \\
\text { equipment. }\end{array}$ & \\
\hline & & $\begin{array}{l}\text { TO5. We have better technological knowledge than } \\
\text { our competitors. }\end{array}$ & \\
\hline & & $\begin{array}{l}\text { TO6. Relative to our competitors, our R\&D programs } \\
\text { are more ambitious to create knowledge among } \\
\text { employees and improving organizations' performance. }\end{array}$ & \\
\hline & & $\begin{array}{l}\text { TO7. Our organization is very proactive in the } \\
\text { construction of innovative technical solutions to } \\
\text { respond to users' needs. }\end{array}$ & \\
\hline \multirow{4}{*}{$\begin{array}{l}\text { Perceived } \\
\text { organizational } \\
\text { usefulness } \\
\text { (PU) }\end{array}$} & Reflective & $\begin{array}{l}\text { PU1: Willingness to utilize sustainable construction } \\
\text { technology and information to fulfil tasks, }\end{array}$ & Davis (1989) \\
\hline & & $\begin{array}{l}\text { PU2: Willingness to spend time to utilize sustainable } \\
\text { construction technology, and }\end{array}$ & \\
\hline & & $\begin{array}{l}\text { PU3: Willingness to recommend sustainable } \\
\text { construction technology to co-workers or other } \\
\text { professionals in a cordial relationship }\end{array}$ & \\
\hline & & $\begin{array}{l}\text { PU4: My organization encourages members of the } \\
\text { organization to use sustainable construction } \\
\text { technology }\end{array}$ & \\
\hline
\end{tabular}




\begin{tabular}{|c|c|c|c|}
\hline \multirow[t]{4}{*}{ Variable name } & \multirow[t]{4}{*}{ Variable type } & $\begin{array}{l}\text { Item description (1-5 Likert scale, } 1=\text { not at all, } 5= \\
\text { completely true) }\end{array}$ & \multirow[t]{2}{*}{ Reference } \\
\hline & & $\begin{array}{l}\text { PU5: My organization is active in working on projects } \\
\text { using sustainable construction technology }\end{array}$ & \\
\hline & & $\begin{array}{l}\text { PU6: My organization has an intention to recommend } \\
\text { sustainable construction technology to other } \\
\text { organizations that we have a cooperative relationship } \\
\text { with. }\end{array}$ & \\
\hline & & $\begin{array}{l}\text { PU7: My organization has an intention to participate in } \\
\text { adopting and developing sustainable construction } \\
\text { technology }\end{array}$ & \\
\hline \multirow{8}{*}{$\begin{array}{l}\text { Environmental } \\
\text { sustainability } \\
\text { performance } \\
\text { (EnSP) }\end{array}$} & Reflective & $\begin{array}{l}\text { EnSP1: Location selection is an important sustainable } \\
\text { construction consideration in our projects }\end{array}$ & Abidin (2005) \\
\hline & & $\begin{array}{l}\text { EnSP2: Material selection is an important sustainable } \\
\text { construction consideration in our projects }\end{array}$ & \\
\hline & & $\begin{array}{l}\text { EnSP3: Waste minimization is an important sustainable } \\
\text { construction consideration in our projects }\end{array}$ & \\
\hline & & $\begin{array}{l}\text { EnSP4: Energy conservation is an important } \\
\text { sustainable construction consideration in our projects }\end{array}$ & \\
\hline & & $\begin{array}{l}\text { EnSP5: Water efficiency is an important sustainable } \\
\text { construction consideration in our projects }\end{array}$ & \\
\hline & & $\begin{array}{l}\text { EnSP6: Pollution control is an important sustainable } \\
\text { construction consideration in our projects }\end{array}$ & \\
\hline & & $\begin{array}{l}\text { EnSP7: Biodiversity protection is an important } \\
\text { sustainable construction consideration in our projects }\end{array}$ & \\
\hline & & $\begin{array}{l}\text { EnSP8: Heritage and amenity protection is an } \\
\text { important sustainable construction consideration in our } \\
\text { projects }\end{array}$ & \\
\hline \multirow{5}{*}{$\begin{array}{l}\text { Economic } \\
\text { sustainability } \\
\text { performance } \\
\text { (EcSP) }\end{array}$} & Reflective & $\begin{array}{l}\text { EcSP1: Life cycle costing is an important sustainable } \\
\text { construction consideration in our company. }\end{array}$ & Abidin (2005) \\
\hline & & $\begin{array}{l}\text { EcSP2: Profitability is an important sustainable } \\
\text { construction consideration in our projects. }\end{array}$ & \\
\hline & & $\begin{array}{l}\text { EcSP3: Business image enhancement is an important } \\
\text { sustainable construction consideration in our projects. }\end{array}$ & \\
\hline & & $\begin{array}{l}\text { EcSP4: Cost management strategy is an important } \\
\text { sustainable construction consideration in our projects. }\end{array}$ & \\
\hline & & $\begin{array}{l}\text { EcSP5: Risk reduction is an important sustainable } \\
\text { construction consideration in our projects. }\end{array}$ & \\
\hline \multirow{4}{*}{$\begin{array}{l}\text { Social } \\
\text { sustainability } \\
\text { performance } \\
\text { (SSP) }\end{array}$} & Reflective & $\begin{array}{l}\text { SSP1: Health and safety is an important sustainable } \\
\text { construction consideration in our projects. }\end{array}$ & Abidin (2005) \\
\hline & & $\begin{array}{l}\text { SSP2: User comfort and satisfaction is an important } \\
\text { sustainable construction consideration in our projects. }\end{array}$ & \\
\hline & & $\begin{array}{l}\text { SSP3: Community welfare is an important sustainable } \\
\text { construction consideration in our projects. }\end{array}$ & \\
\hline & & $\begin{array}{l}\text { SSP4: Accessibility is an important sustainable } \\
\text { construction consideration in our projects. }\end{array}$ & \\
\hline
\end{tabular}




\subsection{Sample and data collection}

The survey items and scales that are used as measuring instruments in this study were initially adopted and subsequently adapted from a broad review of the sustainable construction, technology orientation and perceived usefulness studies (see Table 1). The survey was carried out in 2015 and 2016. The sampling frame included the largest construction firms (the G7 construction firms) operating in West Malaysia, and listed on the Malaysian Construction Industry Development Board (CIDB) website. The copies of the survey instruments were administered by hand while others were sent by post to the construction firms, where one representative (an executive director, a project manager, a marketing manager, an engineer, a quantity surveyor, a contract manager, a sales manager, or an account manager) of the company could respond to the survey. These experts were selected with the understanding that they have knowledge of the sustainability performance in their company's project delivery so that an informed opinion could be provided. Altogether, 172 questionnaires were complete and eligible for data analysis out of the189 total responses collected. Missing values, normality test, outlier's assessment, and multicollinearity test were performed to screen the data prior to data analysis. Moreover, the test of non-response bias was also performed using independent sample $t$-test to determine whether the early respondents provided significantly different values on the measures compared to those that responded after multiple reminder messages. There are no significant differences between the 2 groups. Thus, this study' sample is not affected by non-response bias.

The demographic profiles of the sampled construction firms are indicated in Table 2. The distribution of the firm size reflects a typical representation of construction organizations where employee recruitment is mostly project-based. Accordingly, $69.7 \%$ of the sampled construction firms had employees under 100, while only $16.1 \%$ had more than 500 workers. Also, the respondents were distributed uniformly with respect to their roles in their respected organizations. 
TABLE 2: Sample demographics $(N=172)$.

\begin{tabular}{|l|c|c|}
\hline & Frequency & Percent \\
\hline Firm size (number of employees) & & \\
\hline 500 & 29 & 16.1 \\
\hline $251-500$ & 10 & 5.6 \\
\hline $101-250$ & 13 & 7.6 \\
\hline$<100$ & 120 & 69.7 \\
\hline Total & 172 & 100 \\
\hline Respondent's level & & \\
\hline Executive Director & 20 & 11.6 \\
\hline Project manager & 30 & 17.4 \\
\hline Marketing Manager & 5 & 2.8 \\
\hline Engineer & 30 & 16.7 \\
\hline Quantity Surveyor & 25 & 13.9 \\
\hline Contract Manager & 16 & 8.9 \\
\hline Construction Manager & 13 & 7.2 \\
\hline Others & 33 & 18.3 \\
\hline Total & 172 & 100 \\
\hline
\end{tabular}

\section{Data Analyses and Results}

Structural equation modeling (SEM) was used for data analyses. And, following Ringle et al., (2005), SmartPLS was chosen mainly due to its ability to model the latent constructs both formatively and reflectively (Bamgbade et al., 2019; Petter et al, 2007). The measurement model was first examined, and this was followed by the structural model examination.

\subsection{Measurement model}

To validate the instruments used in this study (for the reflective constructs), the internal consistency, convergent and discriminant validities were examined (Gefen \& Straub, 2005). As SP was operationalized as a second-level construct formed from first-order reflective sub-constructs (i.e., EvSP, EnSP and SSP), the trio of EvSP, EnSP and SSP were included in our measurement model rather than the SP (Teo et al, 2003). Thereafter, the construct's internal consistency was determined using composite reliability (CR). Importantly, PLS-SEM relies on CR measures where the actual loadings are used to calculate the factor scores, and it has been established to be a better measure of internal consistency than the Cronbach's $\alpha$ coefficient (Gotz, Liehr-Gobbers \& Krafft, 2010; Ranganathan et al, 2004). As indicated in Table 3, the CR for all this study's 
constructs in the model were above the recommended threshold of 0.7 (Chin, 1998). The second coefficient (convergent validity) was determined to establish the extent to which the indicators assigned to a scale theoretically are also related to the scale in reality. The information provided in Table 3 indicated the loadings of all the measures in this study's model. All items for measuring the constructs recorded significant path loadings at 0.01 level. As indicated in Table three, the AVE values for all the latent constructs were higher than the recommended 0.50 threshold as advocated by Fornell \& Larcker (1981). These are indications that the convergent validity has been determined in this study.

Discriminant validity is determined to check whether the indicators, in actual fact, measure the latent constructs in the model. According to Fornell and Larcker (1981), the discriminant validity is verified by ascertaining that the square root of the AVE for each construct was higher than the correlations between it and those of other constructs. The results in Table 4 shows the discriminant validity testing in accordance with this method. Similarly, Table 4 also demonstrates that each of the constructs shares greater variance with their own measures than with the other constructs that represent different blocks of measures in the model. Furthermore, the cross-loading technique was observed to assess the discriminant validity of the measuring scales in testing the research model, and the results indicated that all the individual indicator loadings in their corresponding columns are higher than the loadings of the indicators for measuring the other constructs (Chin, 1998). A cursory look across the rows shows that the loading of the items is higher on their corresponding latent constructs than for other constructs in the model. So, the measurements of the reflective constructs in this study have satisfied the two criteria for discriminant validity based on the recommendations of Chin (1998).

\subsection{Structural model}

The estimation of the path coefficient in the outer model (structural model assessment) was done using the PLS-SEM technique. As indicated in Figure 2, the results of the analysis show the predictive power of the model and the estimated path coefficients. The tests of the significance of the hypothesized paths were performed using the bootstrap resampling procedure. Figure 3 shows that all the hypothesized paths in the research model were statistically significant. As predicted earlier, $\mathrm{H} 1$ was supported $(\mathrm{H} 1$ : weight $=0.5376, \mathrm{P}<0.001)$, indicating strong support for $\mathrm{TO}$ in affecting the SP irrespective of the staff strength and the company age. Thus, $\mathrm{H} 1$ is significant. In 
TABLE 3: Psychometric of measurements.

\begin{tabular}{|c|c|c|c|}
\hline Constructs & Item & Loading & t-value \\
\hline Technology Orientation TO (reflective) & TO1 & $0.7322^{* * *}$ & 14.8141 \\
\hline$C R=0.9406$ & TO2 & $0.7937^{* * *}$ & 16.0764 \\
\hline \multirow[t]{7}{*}{ AVE $=0.6381$} & TO3 & $0.8059^{* * *}$ & 18.4459 \\
\hline & TO4 & $0.7940^{* * *}$ & 14.1906 \\
\hline & TO5 & $0.8178^{* * *}$ & 21.3914 \\
\hline & TO6 & $0.7940^{* * *}$ & 20.6989 \\
\hline & TO7 & $0.7686^{* * *}$ & 17.2348 \\
\hline & TO8 & $0.8185^{* * *}$ & 18.1742 \\
\hline & TO9 & $0.8584^{* * *}$ & 27.1534 \\
\hline Perceived Usefulness PU (reflective) & PU1 & $0.7218^{* * *}$ & 13.7628 \\
\hline$C R=0.9377$ & PU2 & $0.7000^{* * *}$ & 8.6777 \\
\hline \multirow[t]{5}{*}{ AVE $=0.6019$} & PU3 & $0.7582^{* * *}$ & 9.4218 \\
\hline & PU4 & $0.6995^{* * *}$ & 12.5366 \\
\hline & PU5 & $0.8125^{* * *}$ & 18.0952 \\
\hline & PU6 & $0.8202^{* * *}$ & 15.9159 \\
\hline & PU7 & $0.8226^{* * *}$ & 16.9867 \\
\hline \multicolumn{4}{|l|}{ Sustainability Performance SP (reflective) } \\
\hline $\begin{array}{l}\text { Environmental Sustainability Performance } \\
\text { (EnSP) }\end{array}$ & EnSP1 & $0.7895^{* * *}$ & 31.0611 \\
\hline$C R=0.9412$ & EnSP2 & $0.8688^{* * *}$ & 37.6634 \\
\hline \multirow[t]{6}{*}{ AVE $=0.6672$} & EnSP3 & $0.7805^{* * *}$ & 22.8701 \\
\hline & EnSP4 & $0.8280^{* * *}$ & 36.3197 \\
\hline & EnSP5 & $0.8083^{* * *}$ & 35.7093 \\
\hline & EnSP6 & $0.8389^{* * *}$ & 28.6206 \\
\hline & EnSP7 & $0.8635^{* * *}$ & 28.5063 \\
\hline & EnSP8 & $0.7497^{* * *}$ & 24.0861 \\
\hline Economic Sustainability Performance (EcSP) & EcSP1 & $0.8224^{* * *}$ & 29.6182 \\
\hline$C R=0.9402$ & EcSP2 & $0.8733^{* * *}$ & 33.3179 \\
\hline \multirow[t]{3}{*}{ AVE $=0.759$} & EcSP3 & $0.8605^{* * *}$ & 31.2627 \\
\hline & EcSP4 & $0.8986^{* * *}$ & 36.4519 \\
\hline & EcSP5 & $0.8988^{* * *}$ & 34.9205 \\
\hline Social Sustainability Performance (SSP) & SSP1 & $0.7316^{* * *}$ & 22.9944 \\
\hline$C R=0.9412$ & SSP2 & $0.8363^{* * *}$ & 35.5242 \\
\hline \multirow[t]{5}{*}{ AVE $=0.6964$} & SSP3 & $0.8612^{* * *}$ & 42.5669 \\
\hline & SSP4 & $0.8539^{* * *}$ & 41.252 \\
\hline & SSP5 & $0.8267^{* * *}$ & 41.423 \\
\hline & SSP6 & $0.8585^{* * *}$ & 42.158 \\
\hline & SSP7 & $0.8654^{* * *}$ & 41.2912 \\
\hline
\end{tabular}

examining the direct effects of perceived usefulness on SP of the sampled construction 
TABLE 4: Variable correlation matrix and AVE.

\begin{tabular}{l|l|l|l|l|l|l|l|} 
& EcSP & EnSP & PU & SP & SSP & TO \\
\hline EcSP & $\mathbf{0 . 8 7 1}$ & & & & & \\
\hline EnSP & 0.620 & $\mathbf{0 . 8 1 7}$ & & & & \\
\hline PU & 0.530 & 0.544 & $\mathbf{0 . 7 7 6}$ & & & \\
\hline SP & 0.852 & 0.896 & 0.606 & $\mathbf{0 . 7 4 9}$ & & \\
\hline SSP & 0.738 & 0.731 & 0.550 & 0.926 & $\mathbf{0 . 8 3 5}$ & \\
\hline TO & 0.625 & 0.626 & 0.654 & 0.704 & 0.638 & $\mathbf{0 . 7 9 9}$ \\
\hline
\end{tabular}

firms, the result indicated that perceived usefulness is strongly related to SP of the construction firms irrespective of company age and staff strength (path coefficient $=$ $0.2539, \mathrm{P}<0.001)$. Therefore, $\mathrm{H} 2$ is also supported.

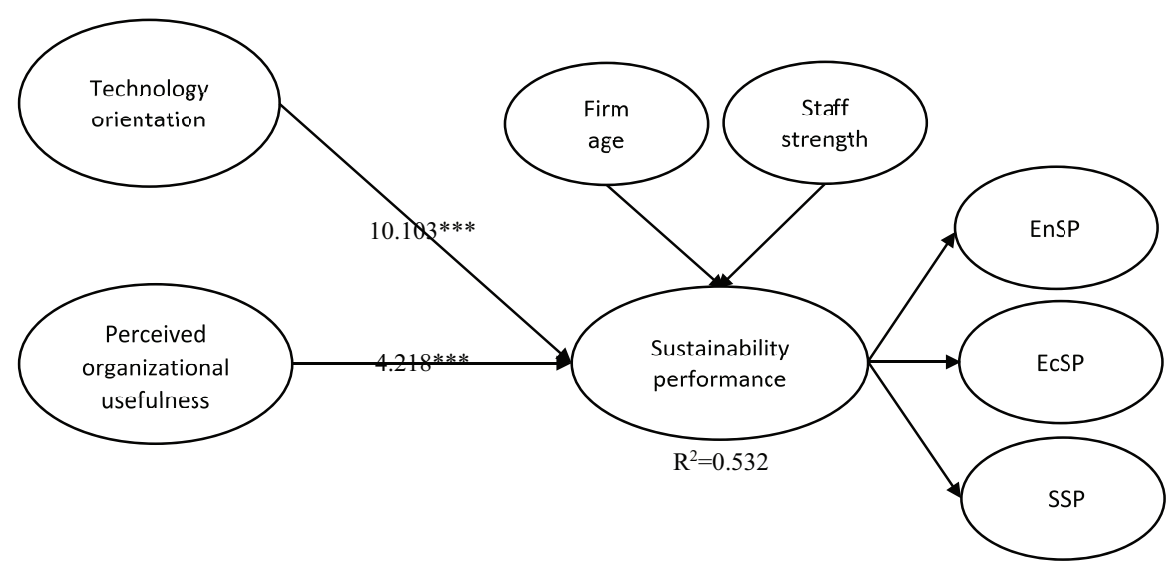

Figure 3: PLS analysis of results (*** significant at 0.01 (1 tailed)).

\begin{tabular}{l|c|c|c|c|c|c|}
\hline Relationships & $\begin{array}{c}\text { Beta } \\
\text { value }\end{array}$ & SD & SE & t-value & p-value & Decision \\
\hline & 0.0029 & 0.0215 & 0.0215 & 0.1343 & 0.45 & \\
\hline $\begin{array}{l}\text { Firm age } \\
\text { Staff strength }\end{array}$ & 0.0021 & 0.0186 & 0.0186 & 0.1106 & 0.46 & \\
$\begin{array}{l}\text { Perceived organizational } \\
\text { usefulness }\end{array}$ & 0.2539 & 0.0602 & 0.0602 & 4.2185 & 0.00 & Supported \\
\hline $\begin{array}{l}\text { Technology orientation } \\
\text { Note: Dependent variable: sustainability performance }\end{array}$ & 0.5376 & 0.0532 & 0.0532 & 10.1036 & 0.00 & Supported \\
\hline
\end{tabular}

\subsubsection{Model's predictive relevance $\left(Q^{2}\right)$ and effect size $\left(f^{2}\right)$}

In evaluating this study's model, variance explained $\left(R^{2}\right)$ values in the endogenous latent constructs, the predictive relevance of the research model $\left(Q^{2}\right)$, and the effect size $\left(f^{2}\right)$ were evaluated. The variance explained $\left(R^{2}\right)$ by the two exogenous latent constructs was 0.532 , after controlling for the demographic variables (in terms of company age 
and staff strength). This suggests that the two predictors (i.e., perceived organizational usefulness and technology orientation) collectively explained $53.2 \%$ of the variance in SP, after controlling for firm age and staff strength. By implication, the criterion variable (SP) has an acceptable $R^{2}$ value since 0.10 was suggested as the minimum $R^{2}$ value (see Hair et al., 2016). The estimation of the effect size $\left(f^{2}\right)$ was achieved by observing the changes that occur in the $R^{2}$ values when one of the predictors is removed from the model. This is done to evaluate the practical effect of the removed predictor on the endogenous construct (Chin, 1998). This was calculated using:

$$
\text { Effect size }\left(f^{2}\right)=\frac{R^{2} \text { included }-R^{2} \text { excluded }}{1-R^{2} \text { included }}
$$

Cohen (1988) suggested the guideline for the assessment of the effect size, which was given as $0.02,0.15$ and 0.35 representing small, medium and large effect sizes respectively. From this model's result, the effect size for technology orientation was 0.35 , and that of perceived organizational usefulness is 0.08 . Therefore, the effect sizes for the two exogenous constructs could be considered as large and small, respectively.

As for the evaluation of the relative predictive relevance of the endogenous latent construct in the structural model, Stone-Geisser criterion $\left(Q^{2}\right)$ was utilized. This $Q^{2}$ criterion was derived through the blindfolding process in SmartPLS with an omission distance of eight (Hair et al., 2016). The $Q^{2}$ value of 0.297 is greater than zero, suggesting an adequate predictive relevance of the reflective endogenous latent variable (Chin, 1998).

\section{Discussions and Conclusions}

Employing sustainable construction practices has been contributing to contractors' performance. However, very few studies have examined the contributions of technology oriented-firms and perceived usefulness of these firms to sustainability performance. Based on the hypothesized paths in this study, the results suggest that technology orientation and organizational perceived usefulness of the sampled firms can have a direct influence on their sustainability performance (in terms of EcSP, EnSP and SSP of the construction firms). First, we assumed that technology orientation would significantly influence the sustainability performance of the sampled contractors ( $\mathrm{H} 1)$. Unsurprisingly, the findings show that there is a significant and positive relationship between the predictor and the criterion variable. This implies that the more technology-oriented a construction firm is, the better they are in sustainability performance. Second, as regards Hypothesis 2, PU also showed a significant positive relationship with sustainability 
performance. This finding indicates that firms (as well as individuals within the firm) with strong belief and capability to utilize sustainable construction system/technology advantageously would enhance their sustainability performance by delivering ecofriendly products, social wellbeing to all stakeholders and achieve economic prosperity.

There are a few practical and theoretical implications of this study. The application of this study's framework can improve contractors' sustainability performance. The framework is a valuable guideline for the Malaysian contractors in developing sustainability policy, strategy and practice towards meeting the requirements for sustainability within the construction industry.

This study is without a few limitations. First, this study is a cross-sectional research design where the data was collected in one-shot, single-point-in-time. This data collection technique precludes causal inferences to be made from the study's population. A different research direction (such as longitudinal research design), is recommended for future studies as this will allow the measurement of the latent constructs at different points in time to confirm this study's findings. Second, the generalization of this study's result is another limitation since only the large firms operating in the Malaysian construction industry were sampled. It was understood that sustainability compliance is an important condition for all firms, however, studies have shown that large firms comply with sustainability policy due to unavoidable government regulations (Bamgbade et al., 2016). Therefore, future research direction should be focused on the inclusion of small and medium construction firms.

\section{References}

[1] Ackerman, M. S., \& Halverson, C. (1998, November). Considering an organization's memory. In CSCW (Vol. 98, pp. 39-48).

[2] Bamgbade, J. A., Kamaruddeen, A. M., Nawi, M. N. M., Adeleke, A. Q., Salimon, M. G., \& Ajibike, W. A. (2019). Analysis of some factors driving ecological sustainability in construction firms. Journal of Cleaner Production, 208, 1537-1545.

[3] Bamgbade, J.A., Kamaruddeen, A.M., \& Nawi, M.N.M. (2017). Towards environmental sustainability adoption in construction firms: An empirical analysis of market orientation and organizational innovativeness impacts. Sustainable Cities and Society, 32, 486-495.

[4] Bamgbade, J. A., Kamaruddeen, A. M., \& Nawi, M. N. M. (2016). Contractors' Environmental Sustainability: The Roles of Innovativeness and Market Orientation. 
International Journal of Supply Chain Management, 5(3), 185-191.

[5] Bhupendra, K. V., \& Sangle, S. (2015). What drives successful implementation of pollution prevention and cleaner technology strategy? The role of innovative capability. Journal of environmental management, 155, 184-192.

[6] Chin W.W. (1998). The partial least squares approach for structural equation modeling. In Modern Methods for Business Research (MARCOULIDES GA, Ed), pp 295-336, Lawrence Erlbaum, Hillsdale, NJ.

[7] Chung, B. Y., Skibniewski, M. J., Lucas Jr, H. C., \& Kwak, Y. H. (2008). Analyzing enterprise resource planning system implementation success factors in the engineering-construction industry. Journal of Computing in Civil Engineering, 22(6), 373-382.

[8] Coelho, A., \& De Brito, J. (2012). Influence of construction and demolition waste management on the environmental impact of buildings. Waste Management, 32(3), 532-541.

[9] Davis, F. D. (1989). Perceived usefulness, perceived ease of use, and user acceptance of information technology. MIS Quarterly, 319-340.

[10] Dooley, D. (2001). Social Research Methods. Prentice-Hall, Upper Saddle River, NJ.

[11] Erek, K., Schmidt, N.-H., Zarnekow, R., Kolbe, L.M., 2009. Sustainability in information systems: assortment of current practices in IS organizations. In: Proceedings of the Americas Conference on Information Systems (AMCIS). San Francisco, August 2009 (paper 123).

[12] Fornell, C., \& Larcker, D. F. (1981). Evaluating structural equation models with unobservable variables and measurement error. Journal of marketing research, 18(1), 39-50.

[13] Gatignon, H., \& Xuereb, J. M. (1997). Strategic orientation of the firm and new product performance. Journal of marketing research, 34(1), 77-90.

[14] Götz, O., Liehr-Gobbers, K., \& Krafft, M. (2010). Evaluation of structural equation models using the partial least squares (PLS) approach. In Handbook of partial least squares (pp. 691-711). Springer, Berlin, Heidelberg.

[15] Gefen, D., \& Straub, D. (2005). A practical guide to factorial validity using PLS-Graph: Tutorial and annotated example. Communications of the Association for Information systems, 16(1), 5 .

[16] Hair, J.F., Hult, G.T.M., Ringle, C.M., Sarstedt, M., 2016. A Primer on Partial Least Squares Structural Equation Modeling (PLS-SEM). 2nd ed.; Sage Publications Inc. Thousand Oaks, CA, USA. 
[17] Kibert, C.J. 2016. Sustainable construction: green building design and delivery. John Wiley \& Sons.

[18] Lee, S., Yu, J., \& Jeong, D. (2013). BIM acceptance model in construction organizations. Journal of Management in Engineering, 31(3), 04014048.

[19] McDonough, W., \& Braungart, M. (2010). Cradle to Cradle: Remaking the way we make things. North point press.

[20] Nam, K. M., Kim, D. W., Cho, H. H., \& Kang, K. I. (2008). Usability analysis on PMIS using technology acceptance model. Proc., Korea Institute of Construction Engineering and Management, Vol. 11, 175-179.

[21] Petter, S., Straub, D., \& Rai, A. (2007). Specifying formative constructs in information systems research. MIS Quarterly 31(4), 623-656.

[22] Ranganathan, C., Dhaliwal, J. S., \& Teo, T. S. (2004). Assimilation and diffusion of web technologies in supply-chain management: an examination of key drivers and performance impacts. International Journal of Electronic Commerce, 9(1), 127-161.

[23] Rangarajan, D., Jones, E., \& Chin, W. (2005). Impact of sales force automation on technology-related stress, effort, and technology usage among salespeople. Industrial Marketing Management, 34(4), 345-354.

[24] Reid, M., \& Brady, E. (2012). Improving firm performance through NPD: The role of market orientation, NPD orientation and the NPD process. Australasian Marketing Journal (AMJ), 20(4), 235-241.

[25] Ringle, C. M., Wende, S., \& Will, A. (2005) SmartPLS (2.0). [www.document] http: //www.smartpls.de (accessed 10 April 2019).

[26] Salimon, M., Bamgbade, J., Nathaniel, A., \& Adekunle, T. (2017). Integrating technology acceptance model and organizational innovativeness in the adoption of mobile commerce. Management Science Letters, 7(10), 497-512.

[27] Salojärvi, H., Ritala, P., Sainio, L. M., \& Saarenketo, S. (2015). Synergistic effect of technology and customer relationship orientations: consequences for market performance. Journal of Business \& Industrial Marketing, 30(5), 511-520.

[28] Teo, H. H., Wei, K. K., \& Benbasat, I. (2003). Predicting intention to adopt interorganizational linkages: An institutional perspective. MIS Quarterly, 19-49.

[29] Venkatesh, V., \& Bala, H. (2008). Technology acceptance model 3 and a research agenda on interventions. Decision Sciences, 39(2), 273-315.

[30] Wong, J. K. W., \& Zhou, J. (2015). Enhancing environmental sustainability over building life cycles through green BIM: A review. Automation in Construction, 57, 156-165. 
[31] Yeheyis, M., Hewage, K., Alam, M. S., Eskicioglu, C., \& Sadiq, R. (2013). An overview of construction and demolition waste management in Canada: a lifecycle analysis approach to sustainability. Clean Technologies and Environmental Policy, 15(1), 81-91.

[32] Yusof, N. A., Abidin, N. Z., Zailani, S. H. M., Govindan, K., \& Iranmanesh, M. (2016). Linking the environmental practice of construction firms and the environmental behaviour of practitioners in construction projects. Journal of Cleaner Production, 121, 64-71.

[33] Zuo, J., \& Zhao, Z. Y. (2014). Green building research-current status and future agenda: A review. Renewable and Sustainable Energy Reviews, 30, 271-281. 